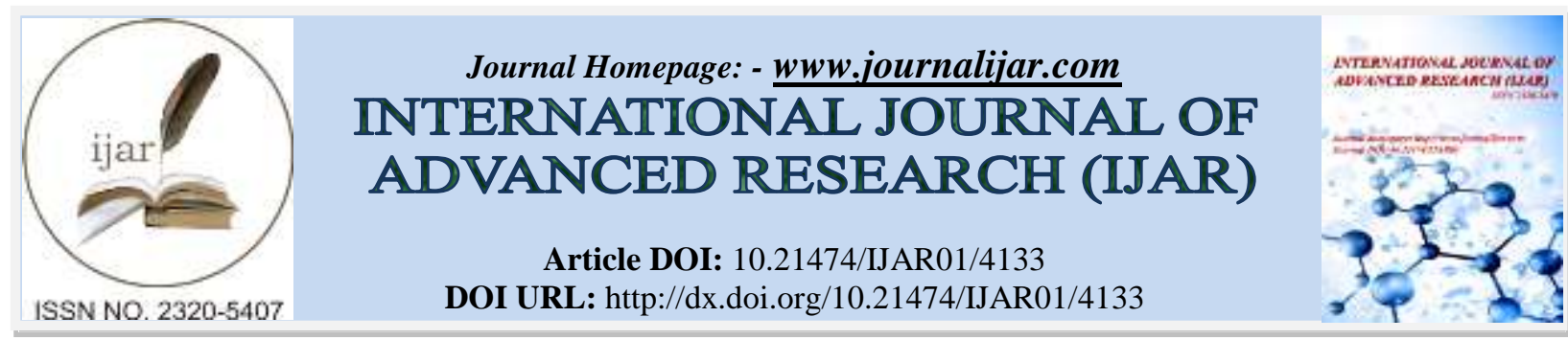

RESEARCH ARTICLE

\title{
ATTITUDE OF FEMALES WORKING IN SOCIALLY ACCEPTED OCCUPATIONS FOR MEN AND WOMEN.
}

\section{Dr. Gauri Kadam ${ }^{1}$ and Yogita Ubhe ${ }^{2}$.}

1. Department of Psychology, Dr.D.Y.Patil Arts, Commerce \& Science College,Pimpri, Pune, Savitribai Phule Pune University, Pune, Maharashtra, India.

2. Department of Behavioural Science, Dr. D. Y. Patil Dental College and Hospital, Dr.D.Y.Patil Vidyapeeth, Pimpri, Pune, Maharashtra, India.

\section{Manuscript Info}

........................

Manuscript History

Received: 07 March 2017

Final Accepted: 09 April 2017

Published: May 2017
Abstract

Copy Right, IJAR, 2017,. All rights reserved.

\section{Introduction:-}

In India, social reformers such as Raja Ram Mohan Roy, Jyotiba Phule, Savitribai Phule, Mahadev Govind Ranade, Ramabai Ranade, Ramabai Saraswati, Maharshi Karve, Pandita Ramabai, etc. fought for the rights and education of women. The practice of child marriage and sati, exploitation of widows were some of the social evils that were prevalent in the society. The social reformers were pioneer in voicing against these evils.

Today the Indian Society has evolved. It is dynamic and tolerant. It has accepted the changing status of girl child, equality in education, sports and careers. Women have been identified with their traditional roles at home and at work place. But now they are venturing in male dominant professions such as drivers, conductors, petrol pump attendants, machine operators, police personnel, post office personnel etc. Most of these professions require physical strength, vigilance, and continuous rigorous time, work in shifts, etc. Hence, women are facing a lot of challenges in the home front as well as work place. This study is an attempt to understand attitude towards androgynization of roles of women who are working in socially accepted occupations for men and women.

\section{Concepts used in present study:-}

Attitude towards androgynization of roles:-

Attitude towards androgynization of roles is a belief that male and female human beings should not be differentiated in role-play on the basis of sex and should be provided with equality of opportunity and freedom to develop in whatever direction their activities and interests dictate. (Anthropologist, 2004).

ATARS has four dimensions which are Model, Prescription of behavior, Reinforcement of behavior and Exposure to varied occupations. Model (M) consists of items related to role model such as female role models should be given only to girls. Prescription of behaviour (PB) includes items that prescribes the behaviour of boys and girls. Reinforcement of behaviour (RB) consists of items like "boys should not be scolded if they shy like girls and if boys behave like girls, they should be teased". Exposure to varied occupations (EVO) includes items such as "Boy's work efficiency is more than girls; girls have stereotypical vocations like teaching". (Manual for Attitude Towards Androgynization of Roles Scale, 1987). 


\section{Socially accepted occupations for men:-}

Occupations assigned to males such as petrol pumps, security services, post office, restaurants, transportation and police services. (Vieira et.al, 2008).

Socially accepted occupations for women:-

Occupations assigned to females such as nursing, saloons, teaching, governess, etc

\section{Statement of the problem:-}

A study of attitude towards androgynization of roles among females working in socially accepted occupations for men and women.

\section{Objectives of the study:-}

- To study attitude towards androgynization of roles among females.

- To study females working in socially accepted occupations for men and women.

\section{Review of Literature:-}

Mahajan, Sharma \& Sharma (2004) in their study 'Attitude Towards Androgynization of Roles' found that there was no significant difference between ATARS, Model, Prescription of Behaviour, Reinforcement of Behaviour and Exposure to varied occupations of male and female students.

Kadam \& Ubhe (2016) found in the study 'Attitude towards Androgynization of roles and emotional maturity among males and females working in male dominated professions' that there was gender difference $(\mathrm{t}=6.88)$ on attitude towards androgynization of roles among individuals working in male dominated professions, gender difference $(\mathrm{t}=5.15)$ on Model as dimension of ATARS, gender difference $(\mathrm{t}=5.97)$ on Prescription of Behaviour) as dimension of ATARS, gender difference ( $\mathrm{t}=5.61)$ on Reinforcement of Behaviour as dimension of ATARS, gender difference $(\mathrm{t}=5.74)$ on Exposure to varied occupations $(\mathrm{EVO})$ as dimension of ATARS.

Kadam \& Ubhe (2016) in the study,' Attitude towards androgynization of roles and emotional maturity among individuals working in female dominated professions' results showed that there was no gender difference $(\mathrm{F}=0.47)$ in attitude towards androgynization of roles among individuals working in female dominated professions, no gender difference $(\mathrm{F}=0.023)$ in Model as dimension of ATARS, no gender difference $(\mathrm{F}=1.33)$ in Prescription of Behaviour) as dimension of ATARS, no gender difference $(\mathrm{F}=0.00)$ in Reinforcement of Behaviour as dimension of ATARS, no gender difference $(\mathrm{F}=0.36)$ in Exposure to varied occupations $(\mathrm{EVO})$ as dimension of ATARS.

\section{Hypotheses:-}

1. There will be no difference in attitude towards androgynization of roles among females working in socially accepted occupations for men and females working in socially accepted occupations for women.

2. There will be no difference in Model as a dimension of ATARS among females working in socially accepted occupations for men and females working in socially accepted occupations for women.

3. There will be no difference in Prescription of Behaviour as a dimension of ATARS among females working in socially accepted occupations for men and females working in socially accepted occupations for women.

4. There will be no difference in Reinforcement of Behaviour as a dimension of ATARS among females working in socially accepted occupations for men and females working in socially accepted occupations for women.

5. There will be no difference in Exposure to varied occupations as a dimension of ATARS among females working in socially accepted occupations for men and females working in socially accepted occupations for women.

\section{Methodology:-}

\section{Sample:-}

A sample of 115 females was selected from Pune city, Maharashtra, India with a minimum formal education of 10 years, age ranging from 20 to 40 years. One group consisted of 65 females in socially accepted jobs for men such as manufacturing units, state transport service, private cabs, petrol pumps, and another of 50 females from socially accepted jobs for women such as nursing, saloons, beauty parlors etc. 


\section{Tools:-}

\section{Attitude Towards Androgynization of Roles Scale by Bisht (1987)}

The Attitude Towards Androgynization of Roles Scale is devised by Bisht, which comprises of 60 items in total and is divided into 4 dimensions which are Models (M) Prescription of behaviour (PB), Reinforcement of behaviour (RB), Exposure to varied occupations (EVO). The reliability was chalked out by split-half method by applying S-B formula. It was .98 which is satisfactory. ATARS has construct validity. This scale was reliable and valid. Scoring is done as per manual. It is used for adults.

\section{Results and Discussion:-}

\section{Quantitative results:-}

Table 1:- Mean, SD, ' $t$ ' values of females in ATARS

\begin{tabular}{|c|c|c|c|c|c|c|}
\hline \multirow{2}{*}{ Variables } & Category & $\mathrm{N}$ & Mean & $\begin{array}{c}\text { Standard } \\
\text { Deviation }\end{array}$ & ' $\mathrm{t}$ ' value & $\mathrm{df}$ \\
\hline \multirow{2}{*}{ ATARS } & $\begin{array}{c}\text { Females in socially accepted } \\
\text { occupations for men }\end{array}$ & 65 & 80.82 & 14.86 & 1.32 & \multirow{2}{*}{113} \\
\cline { 2 - 6 } & $\begin{array}{c}\text { Females in socially accepted } \\
\text { occupations for women }\end{array}$ & 50 & 77.30 & 13.13 & (N.S) & \\
\hline
\end{tabular}

N.S : Not Significant

Table 1 shows that Mean and S.D. in ATARS of females in socially accepted occupations for men is 80.82 and 14.86 , females in socially accepted occupations for women is 77.30 and 13.13 respectively. The ' $t$ ' value is 1.32 , not significant at 0.05 or 0.01 level. Hence, the hypothesis that there will be no difference in attitude towards androgynization of roles among females working in socially accepted occupations for men and females working in socially accepted occupations for women is accepted.

It shows that there is no difference in both groups, in attitude that males and females should not be differentiated in their occupations on basis of gender.

Table 2:- Mean, SD, 't' values of females in Model as a dimension of ATARS

\begin{tabular}{|c|c|c|c|c|c|c|}
\hline Variables & Category & $\mathrm{N}$ & Mean & $\begin{array}{c}\text { Standard } \\
\text { Deviation }\end{array}$ & 't' value & df \\
\hline \multirow{2}{*}{$\begin{array}{c}\text { Model } \\
(\mathrm{M})\end{array}$} & $\begin{array}{c}\text { Females in socially accepted } \\
\text { occupations for men }\end{array}$ & 65 & 25.92 & 5.78 & \multirow{2}{*}{$3.52 *$} & 113 \\
\cline { 2 - 6 } & $\begin{array}{c}\text { Females in socially accepted } \\
\text { occupations for women }\end{array}$ & 50 & 29.26 & 3.86 & & \\
\hline
\end{tabular}

*significant at 0.05 level

Table No 2 shows that Mean and S.D in Model of females in socially accepted occupations for men is 25.92 and 5.78 , females in socially accepted occupations for women is 29.26 and 3.86 respectively. The ' $t$ ' value is 3.52 , significant at 0.05 level. Hence, the hypothesis that there will be no difference in Model as a dimension of ATARS among females working in socially accepted occupations for men and females working in socially accepted occupations for women is rejected.

It shows that there is difference in attitude in both the groups in the belief that female role-model should be given to girls and male role-model to boys.

Table 3:- Mean, SD, 't' values of females in Prescription of Behaviour as a dimension of ATARS

\begin{tabular}{|c|c|c|c|c|c|c|}
\hline Variables & Category & $\mathrm{N}$ & Mean & $\begin{array}{c}\text { Standard } \\
\text { Deviation }\end{array}$ & 't' value & df \\
\hline $\begin{array}{c}\text { Prescription of } \\
\text { Behaviour } \\
\text { (PB) }\end{array}$ & $\begin{array}{c}\text { Females in socially } \\
\text { accepted occupations for } \\
\text { men }\end{array}$ & 65 & 26.43 & 6.05 & \multirow{2}{*}{$3.55^{*}$} & 113 \\
\cline { 2 - 5 } & $\begin{array}{c}\text { Females in socially } \\
\text { accepted occupations for } \\
\text { women }\end{array}$ & 50 & 22.12 & 6.94 & & \\
\hline
\end{tabular}

*significant at 0.05 level 
Table No 3 shows that Mean and S.D in Prescription of Behaviour of females in socially accepted occupations for men is 26.43 and 6.05, females in socially accepted occupations for women is 22.12 and 6.94 respectively. The ' $t$ ' value is 3.55 , significant at 0.05 level. Hence, the hypothesis that there will be no difference in Prescription of Behaviour as a dimension of ATARS among females working in socially accepted occupations for men and females working in socially accepted occupations for women is rejected.

It shows that there is a difference in the attitude towards boys and girls behavior should be specific as per gender.

Table 4:- Mean, SD, ' $\mathrm{t}$ ' values of females in Reinforcement of Behaviour as a dimension of ATARS

\begin{tabular}{|c|c|c|c|c|c|c|}
\hline Variables & Category & $\mathrm{N}$ & Mean & $\begin{array}{l}\text { Standard } \\
\text { Deviation }\end{array}$ & ' $t$ ' value & df \\
\hline \multirow{2}{*}{$\begin{array}{l}\text { Reinforcement of } \\
\text { Behaviour } \\
\text { (RB) }\end{array}$} & $\begin{array}{c}\text { Females in socially accepted } \\
\text { occupations for men }\end{array}$ & 65 & 14.37 & 3.17 & \multirow{2}{*}{$3.58 *$} & \multirow{2}{*}{113} \\
\hline & $\begin{array}{c}\text { Females in socially accepted } \\
\text { occupations for women }\end{array}$ & 50 & 12.34 & 2.80 & & \\
\hline
\end{tabular}

*significant at 0.05 level

Table No 4 shows that Mean and S.D in Reinforcement of Behaviour of females in socially accepted occupations for men is 14.37 and 3.17 , females in socially accepted occupations for women is 12.34 and 2.80 respectively. The ' $t$ ' value is 3.58 , significant at 0.05 level. Hence, the hypothesis that there will be no difference in Reinforcement of Behaviour as a dimension of ATARS among females working in socially accepted occupations for men and females working in socially accepted occupations for women is rejected.

It shows that gender specific behavior should not be reinforced and behavior that is not specific with the gender should not be encouraged.

Table 5:- Mean, SD, 't' values of females in Exposure to varied occupations as a dimension of ATARS

\begin{tabular}{|c|c|c|c|c|c|c|}
\hline Variables & Category & $\mathrm{N}$ & Mean & $\begin{array}{c}\text { Standard } \\
\text { Deviation }\end{array}$ & ' $\mathrm{t}$ ' value & df \\
\hline \multirow{2}{*}{$\begin{array}{l}\text { Exposure to varied } \\
\text { occupations (EVO) }\end{array}$} & $\begin{array}{l}\text { Females in socially } \\
\text { accepted occupations for } \\
\text { men }\end{array}$ & 65 & 14.09 & 3.36 & \multirow{2}{*}{$\begin{array}{l}0.82 \\
(\mathrm{~N} . \mathrm{S})\end{array}$} & \multirow{2}{*}{113} \\
\hline & $\begin{array}{l}\text { Females in socially } \\
\text { accepted occupations for } \\
\text { women }\end{array}$ & 50 & 13.58 & 3.26 & & \\
\hline
\end{tabular}

N.S : Not Significant

Table No 5 shows that Mean and S.D in EVO of females in socially accepted occupations for men is 14.09 and 3.36 , females in socially accepted occupations for women is 13.58 and 3.26 respectively. The ' $t$ ' value is 0.82 , not significant at 0.05 or 0.01 level. Hence, the hypothesis that there will be no difference in Exposure to varied occupations as a dimension of ATARS among females working in socially accepted occupations for men and females working in socially accepted occupations for women is accepted.

It shows that there is difference in the belief that males and females would be more efficient in work that is gender specific.

Qualitative analysis:-

Females working in socially accepted occupations for men reported that

1. They got co-operation from their colleagues, management and their clients.

2. The women conductors reported that they were degraded by their husbands and in-laws.

3. They were getting less salary than their male counterparts though the job definition is the same.

4. In some petrol pumps, they were being teased by the clients.

\section{Conclusion:-}

1. There was no difference in attitude towards androgynization of roles (ATARS) and Exposure to varied occupations as a dimension of ATARS among females working in socially accepted occupations for men and women working in socially accepted occupations for women. 
2. There was difference in Model as a dimension of ATARS, in Prescription of Behaviour and in Reinforcement of Behaviour among females working in socially accepted occupations for men and females working in socially accepted occupations for women.

\section{References:-}

1. Bisht.A.R.(1987). Manual for Attitude Towards Androgynization of Roles Scale, National Psychological Corporation, Agra.

2. Kadam.G. \& Ubhe.Y.(2016). Attitude towards Androgynization of roles and emotional maturity among males and females working in male dominated professions. International Journal of Sciences \& Applied Research. $3(9), 21-29$

3. Kadam.G. \& Ubhe.Y.(2016).Attitude towards androgynization of roles and emotional maturity among individuals working in female dominated professions.International Journal of Applied Research. 2(8), 596-601.

4. Mahajan.P., Sharma.N.,\& Sharma.S.(2004).Attitude Towards Androgynization of Roles, Anthropologist,6(3), 181-183

5. Vieira.C.,Saavedra.L.,Araujo.A,Silva.A,Loureiro.T,L.Faria.L.,Ferreira.S.,Taveira.M. (2008).Girls' perceptions about what is required to have success in male dominated professional areas: gender stereotypes under vocational choices. International conference: The future of education. 35. 